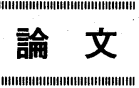

\author{
微粉炭燃焼フライアッシュ中の炭素分の性状 \\ (キーワード フライアッシュ, 炭素分, 灰分, 分級) \\ - 1993.11.18 受理一
}

名古屋大学 陳 勇, 森 滋勝

\section{1. 緒 言}

石炭燃焼に伴い，原炭の約 $15-20 \%$ 相当量の石炭灰 が発生する。微粉炭燃焼ボイラより排出される石炭灰 の世界的年間発生量は約 4 億 $\mathrm{t}$ を越えている。このよ うに大量の石炭灰をできるだけ多量に資源として有効 利用することは環境保善上極めて重要である。

石炭灰を有効に利用する手段として，(1)セメント ・ コンクリート材料，(2)アスファルト舗装混合剤や路盤 剤，(3)農作物の肥料などがある1)。しかし，石炭灰中 に多量の炭素分が含有していると燃焼効率の低下だけ でなく，石炭灰の資源化，有効利用に抢いての大きな 支障となる2)

石炭燃焼における灰中の炭素分を低減するためには， その発生原因を究明することが重要である。

従来, 石炭灰中に炭素分が存在する原因としては, NOx 規制の強化に対応するための低酸素燃焼および 2 段燃焼などと, 低品位炭の使用によるものとされて きた。近年, 小島ら ${ }^{3)}$ は, 高温における燃焼の場合, 粒子表面の生成灰層が溶融し, 酸素の拡散阻害を引き 起こすため, 燃焼が完結せずに未燃炭素分が残ると指 摘した。

著者ら ${ }^{4) 5}$ は石炭灰の特性よりこの炭素分の発生原 因を解明する観点から，微粉炭燃焼フライアッシュの 特性を調ベ, フライアッシュを分級すると, 粗大粒子 側の炭素分含有量が微細粒子側のそれよりかなり多く なることと, 微粉炭燃焼フライアッシュ中の炭素分の 燃焼性は同種炭チャーのそれより劣ることを明らかに した。

本研究では, 上述の研究結果に基づいて, さらに, 微細フライアッシュ成分と粗大フライアッシュ成分中 に含まれている炭素分の諸特性を検討する。同一の事

工学部分子化学工学科 名古屋市千種区不老町
業用微粉炭燃焼ボイラから排出された二種類のフライ アッシュを粒径 $38 \mu \mathrm{m}$ 以下の成分と $125 \mu \mathrm{m}$ 以上の 成分とに分級し, 各成分ごとに超音波オイル・アグロ レーション法によって炭素分をフライアッシュから分 離する。成分ごとに含まれている炭素分の性状を EDX (Energy Dispersive X-Ray Micro Analyzer, EMAX-2770), 電子顕微鏡 (SEM), X 線回折および 高温熱分析法によって調べる。さらに, 微細炭素分粒 子 $(38 \mu \mathrm{m}$ 以下 $)$ と粗大炭素分粒子 (125 $\mu \mathrm{m}$ 以上)の 性状の差異より，フライアッシュ中の炭素分の発生原 因を追究し，それに与える燃焼装置，燃焼条件および 炭種などの影響を推測する。

\section{2. 実 験}

使用した試料としては典型的なフライアッシュの例 として同一の事業用微粉炭燃焼ボイラから排出された, 通常の燃焼性を示す歴青炭を燃焼した未燃炭素分含有 率 $9.1 \%$ のフライアッシュ E と，良好な燃焼性を示す 垔歴青炭を燃焼したにもかかわらず，12.7\%と高い未 燃炭素分含有率のフライアッシュ $\mathrm{G}$ を採用した。これ らを粒径 $38 \mu \mathrm{m}$ 以下の成分と $125 \mu \mathrm{m}$ 以上の成分と に分級し，各成分ごとに超音波オイル・アグロレー ション法によって炭素分をフライアッシュから分離し た。

各成分中に含まれる炭素分と灰分に対して，それぞ れ SEM と EDX によって, 試料粒子の表面形状を観 察し, X線回折によって, 炭素分の構造変化を調べ, さらに, 高温熱分析器 (TG) を用いて, 炭素分の燃 焼反応性を測定した。

\section{3. 結 果}

\section{1 炭素分の収支}

Fig. 1 に分級, 分離の過程における両試料中の炭素 分含有量の变化と炭素分収支を示している。フライ 

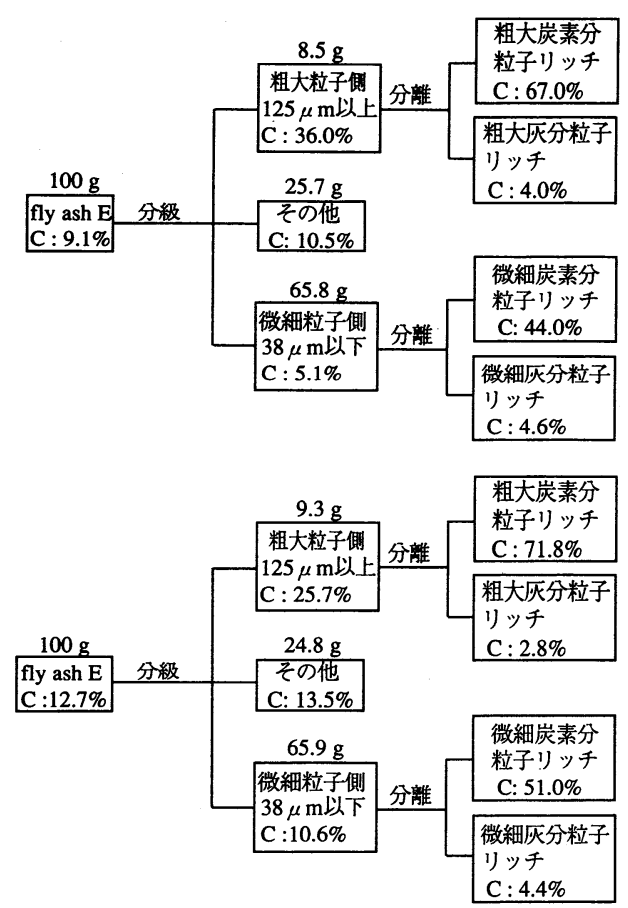

Fig. 1 Carbon balances during clasification and separation processes

アッシュ $\mathrm{E} の 38 \mu \mathrm{m}$ 以下の成分中の炭素分は全炭素 分の $36.9 \%, 125 \mu \mathrm{m}$ 以上の成分中の炭素分は全炭素 分の $33.6 \%$ あるるが，フライアッシュ Gの $38 \mu \mathrm{m}$ 以 下の成分中の炭素分は全炭素分の $54.9 \%, 125 \mu \mathrm{m}$ 以 上の成分中の炭素分は全炭素分の $18.8 \%$ あり，微細 炭素分粒子が極めて高い值となっている。このことか ら, 同一の微粉炭燃焼炉から排出された両試料中の炭 素分の発生機構はかなり違っており, 炭種の影響を強 く受けていることが分かる。

\section{2 フライアッシュ中の灰分の表面形状}

Fig. 2 に 2 種類のフライアッシュ中の粗大灰分粒子 (125 $\mu \mathrm{m}$ 以上) と微細灰分粒子 $(38 \mu \mathrm{m}$ 以下)の表面 形状の電子顕微鏡写真を示す。粗大扊分粒子は表面が 溶けて, 不定形状を呈している。これに対して, 微細 灰分粒子はほぼ球状を呈している。

微細疢分粒子が高温の火炎域下で溶融し，炉内にお ける空気流の旋回等によって球状となるが，粗大扊分 粒子の場合は，粒径が大きいため，粒子表面より中心 部への伝熱速度は粒子の高温の火炎域を通過する速度 よりかなり遅いため, 粒子表面だけが溶けて, 輪郭を 失なうが, 球状とならなかったものと考えられる。

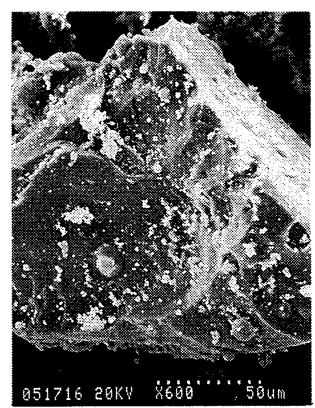

$125 \mu \mathrm{m} \sim$

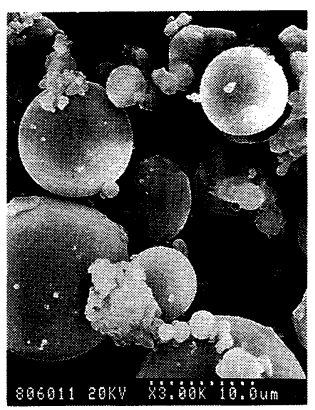

$\sim 38 \mu \mathrm{m}$ (a) fly ash E

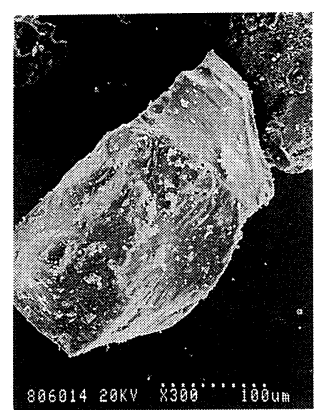

$125 \mu \mathrm{m} \sim$

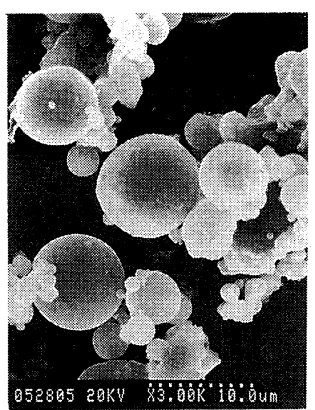

$\sim 38 \mu \mathrm{m}$ (b) fly ash G

Fig. 2 SEM photographs of larger and smaller ash in fly ash $E$ and $G$

\section{3 炭素分の形態}

Fig. 3 (a)，(b)，Fig. 4 (a)，(b)にそれぞれ EDX に より判断された粗大炭素分粒子と微細炭素分粒子の表 面形状の電子顕微鏡写真を示す。粗大炭素分粒子は多 孔質石炭チャーとして残存している (Fig. 3 (a), (b)) が, 微細炭素分粒子の一部分は塊状（板状）を呈して いる(Fig. 4 (a), (b))。

さらに, Fig. 4 の二種類の微細炭素分粒子の表面形 状を Fig. 5 に示している黒鉛粒子（東海カーボン製 G 2080塊状人造黑鉛）のそれと比較すると，両者の表 面形状が類似していることは分かる。これは微細炭素 分粒子は火炎の高温下で不定形炭素の六員環構造が変 化して，結晶化へ進んでいく ${ }^{5)}$ ため考えられる。

\section{4 炭素分の X 線回折}

Fig. 6 に二種類フライアッシュ中に含まれる粗大炭 素分粒子と微細炭素分粒子の X 線回折試験の結果を示 す。いずれのフライアッシュでも，粗大炭素分粒子の 場合には, 石炭の不定形炭素のピークが大きく現れて いるが，微細炭素分粒子の場合では，不定形炭素の 


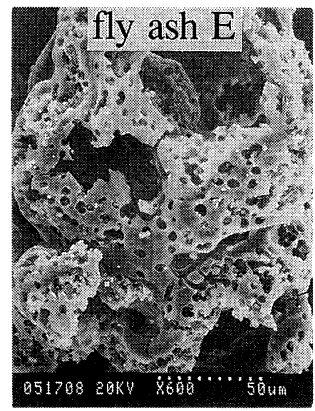

(a)

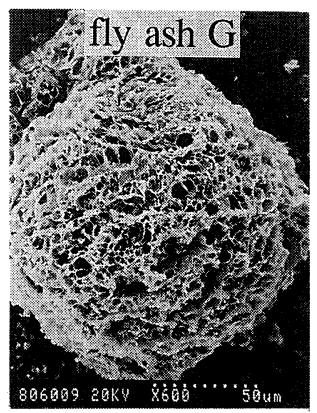

(b)
Fig. 3. SEM photographs of larger carbons in fly ash $E$ and $G$

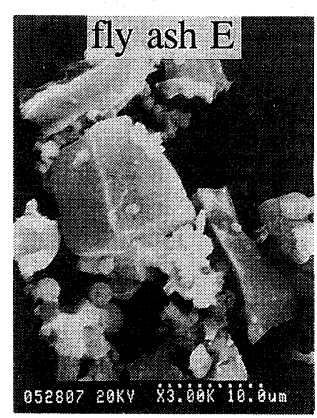

(a)

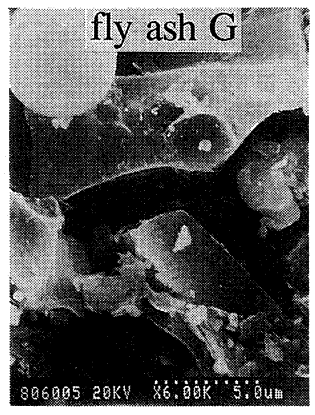

(b)
Fig. 4 SEM photographs of smaller carbons in fly ash $E$ and $G$

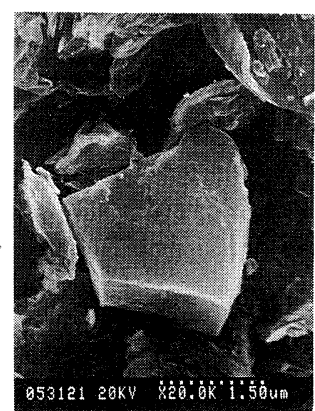

Fig. 5 SEM photograph of graphite

ピークがかなり平坦なものとなり, $2 \theta=26.4^{\circ}$ に炭 素の結晶ピークが検出される。このことから炭素結晶 物はカーボンブラックであるか，あるいは観察された 塊状の炭素分である。

また, Fig. 6 の微細炭素分粒子の X 線回折結果で は， $2 \theta 29^{\circ}$ 付近により大きなピークが現れている。 これは $\mathrm{SO}_{3}$ の結晶ピークとも考えられるが，今後の検 討課題である。

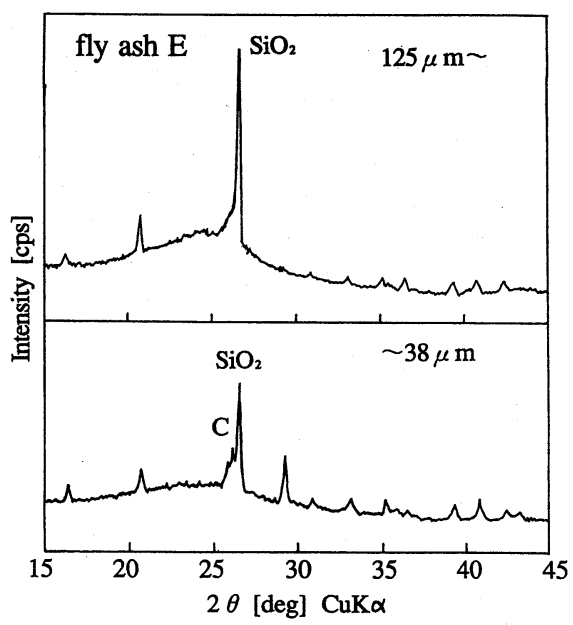

(a)

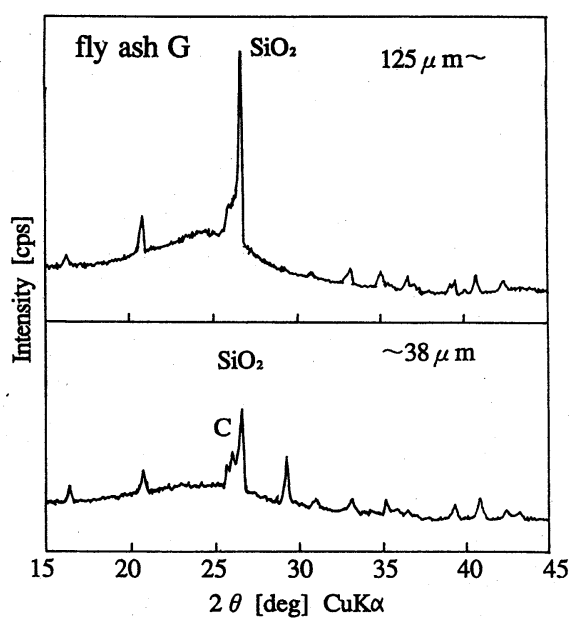

(b)

Fig. $6 \mathrm{X}$-ray diffraction patterns of larger and smaller carbon in fly ash $E$ and $G$

\section{5 熱分析による炭素分の燃焼性の評価}

さらに，粗大と微細炭素分粒子の燃焼性の相違を論 ずるために，繰り返して熱分析実験を行い，より再現 性が得られることを確かめている。

Fig. 7 にG による粗大炭素分粒子, と微細炭素分 粒子及びグラファイト粒子の燃焼反応曲線を示す。粗 大炭素分粒子の $\mathrm{S}$ 字形燃焼反応曲線と異なって, 微細 炭素分粒子の燃焼反応曲線は二段階（図中 Aの部分） を呈している。第一段階目においては，微細炭素分粒 子の燃焼挙動が粗大炭素分粒子のそれとほぼ同じであ るが，微細炭素分粒子の方は構造変化が起こったため， 燃焼反応性は粗大炭素分粒子のそれより若干劣ること が認められた。第二段階目においては，この段階の燃 


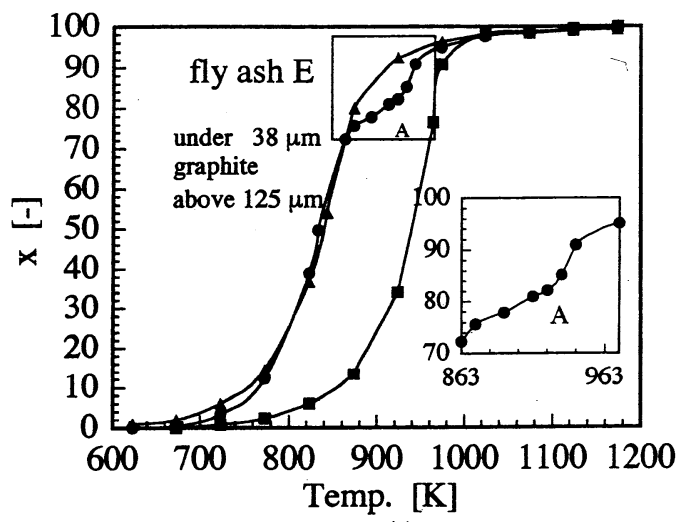

(a)

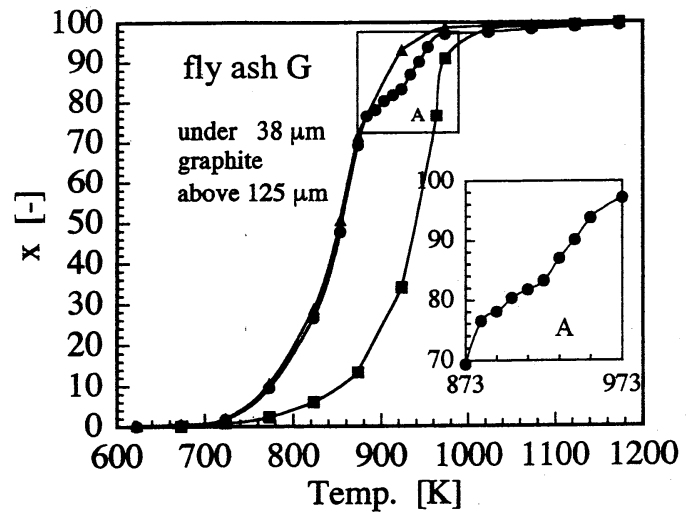

(b)

Fig. 7 TG curves of larger and smaller carbon in fly ash E, G and graphite

焼開始温度は約 $650^{\circ} \mathrm{C}$ であり，グライファイト粒子の 最大燃焼速度を示す温度とほほ一致する。これらのこ とから，この部分の炭素分は全炭素分の約 $20 \%$ 占め, カーボンブラックである可能性が大きい。

\section{4. 考察}

\section{1 炭素分の発生原因}

フライアッシュ中に残存する炭素分の発生原因につ いて粗大炭素分と微細炭素分とに分けて考察する。

一般に, 微粉炭燃焼の際に使われる石炭は200メッ シュ $(74 \mu \mathrm{m})$ 通過率70 80\% 程度に粉砕したもので あり，燃焼炉と燃焼条件もこの基準に基づいて設計， 設定されているので， $74 \mu \mathrm{m}$ 以上の石炭粒子，特に $125 \mu \mathrm{m}$ 以上のものが燃焼しきらずに残存する可能性 は大きい。一方，微細石炭粒子は一個粒子当たりの反 応速度が十分速いため, 炉内で完全燃焼するはずであ る。しかし，石炭より生じた揮発分と燃焼時に発生し た $\mathrm{CO}_{2}, \mathrm{CO}$ ガスによる遮断作用により酸素の拡散を 阻害して，火炎域の局部か酸素不足となり，一部分の
石炭粒子は燃焼しきらず，高温，欠酸素の条件下で石 炭の構造変化が起こって, 塊状となるものが存在する と推定される。

さらに，同一の理由により揮発分の不完全燃焼のた めに，揮発分中の炭化水素は重合し，脱水素とともに 環状化が進行してベンゼン縮合環を形成し，カーボン ブラックとして析出するものも存在すると考えられる。

このようにフライアッシュ中の炭素分の発生原因の 観点から，燃焼炉の構造，特にバーナーの構造は炭素 分形態に顕著な影響を与えるものと考えられる。

\section{2 石炭燃焼性のテストへの再検討}

従来, 石炭の燃焼性を評価する簡単な方法としては, 石炭の工業分析值から算出される燃料比が高いほど燃 焼性が悪いと判断したり，20mg 程度の少量微粉炭サ ンプルを電気炉に入れ，空気中で $15-20 \mathrm{~K} / \mathrm{min}$ の加熱 速度で加熱してその重量変化を測定する Burning Profile 法 ${ }^{6)}$-8), 試験用の燃焼バーナーでその燃焼性 を評価するなどの方法が使用されてきた。しかし，本 研究の結果によると, 同一の燃焼炉から得られたフラ イアッシュ Eと G中の炭素分の粒度別含有率と存在形 態がかなり異なることが明らかになった。特に，事前 の試験用の燃焼バーナーによる焼性テストでは燃焼性 が優れると判断された石炭 G（Fig. 3（b)に示してい る同炭チャーの表面形状からもこの石炭はより燃焼性 が良い石炭であることが分かる）は微細フライアッ シュ中に相当量の炭素分が残存し，高い炭素分含有率 となっている。このように, フライアッシュ中に残存 する炭素分や燃焼効率の推算を行うためには，従来の 燃焼性テストだけでは不十分であり，本研究のように， 実ボイラで発生したフライアッシュ中の炭素分の粒度 別含有量とその形態を検討することが重要であり，こ の知見に基ついて，炭種に適合した操作条件の設定と バーナー構造の選択を行う必要があると考えられる。

\section{5. 結 言}

同一の微粉炭燃焼ボイラから排出された二種類のフ ライアッシュを用いて, 熱分析, X線回折，マイクロ 観察などの手法でその中に含有している炭素分の特性 を調べた結果，以下の知見を得た。

(1) 粗大フライアッシュ成分中には炭素分が未燃の 石炭チャーの状態で残存するが, 微細フライアッシュ 成分中にはカーボンブラックおよび塊状の炭素分が存 在する。

(2) 同一燃焼炉から排出されたフライアッシュ $\mathrm{E} お$ よびと $\mathrm{G} に$ 含まれる炭素分の含有率とその存在形態が かなり異なる。特に，事前の燃焼性のテストで燃焼性 
が優れると判断された石炭 $\mathrm{G}$ は微細フライアッシュ中 に相当量の炭素分が含有し, 高い炭素分含有率となっ ている。

(3) フライアッシュ中の炭素の粒度別含有量とその 存在形態を検討することによって，炭種に適合した操 作条件の設定とバーナー構造の選択を行う必要がある。

\section{(謝 辞)}

当該研究は名古屋大学工学部高温エネルギー変換研 究センターとの共同研究の一部分である。

また，本研究の一部は通産省の新エネルギー・産業 技術総合開発機構 (NEDO) の研究基金の支援によるも のである。記して謝意を表します。

注：第30回石炭科学会議（東京，1993年10月）にて発 表

$$
\text { 文 献 }
$$

1）三島敦夫, 安全工学, 30，(1)，18-32 (1991)
2) "Coal fly ash utilization technology", Reported by Coal Technology Research Center, 25-29, (1981)

3）小島紀徳，他，燃協誌，65，(3)，194-202 (1986)

4) 森 滋勝, 岩崎 昇, 澤智 昭, 満仲三正, 浮田 和明, 石井光浴, 野尻拓男, 宇都宮康晴, 化学工 学会第58回研究発表講演要旨集, 138-138 (1993)

5) 陳 勇, 松田仁樹, 架谷昌信, 化学工学論文集, 19, (1), 48-54 (1993)

6) Wagoner, C. L., et al., ASME Publication, 67-WA/FU-4, (1967)

7) Bryers, R. W., et al., Coal Technology' 78, Houston, TX (1978)

8) Cumming, J. W., et al., Thermochimica Acta, 57, (3), 253-260 (1982)

\title{
Properties of Carbon Containing in Fly Ash Discharged from Pulverized Coal Combustion Boiler
}

\author{
Yong CHEN and Shigekatsu MORI
}

(Department of Chemical Engineering, Nagoya University)

SYNOPSIS : - Fly ashes $E$ and $G$ those discharged from a same pulverized coal combustion boiler were classified into two components, such as smaller fly ash particle under $38 \mu \mathrm{m}$ and larger fly ash particle above $125 \mu \mathrm{m}$. The carbon cotained in both components were separated from fly ash by using the Ultrasonic Oil Agglomeration method. Properties of separated carbons were investigated by applying the X-ray diffraction, SEM (Scanning Electron Microscope), EDX (Energy Dispersive X-Ray Micro Analyzer) and TGA (Thermogravimetric Analysis). Following results are obtained.

(1) The carbon remains in the larger fly ash as the unburned char, and that cotained in smaller fly ash are carbon black and rock carbon.

(2) Significant differences of the carbon contents and their properties between the fly ashes $E$ and $G$ are found. The carbon content in smaller components of fly ash $G$ is fairly greater than that in smaller components of fly ash $E$, although the coal $G$ shows a good combustibility.

These observations of the properties of carbon containing in fly ash present significant informations on the for rational operation and control in the process of pulverized coal combustion process.

\section{Key Words}

Fly ash, Carbon, Ash, Classify 